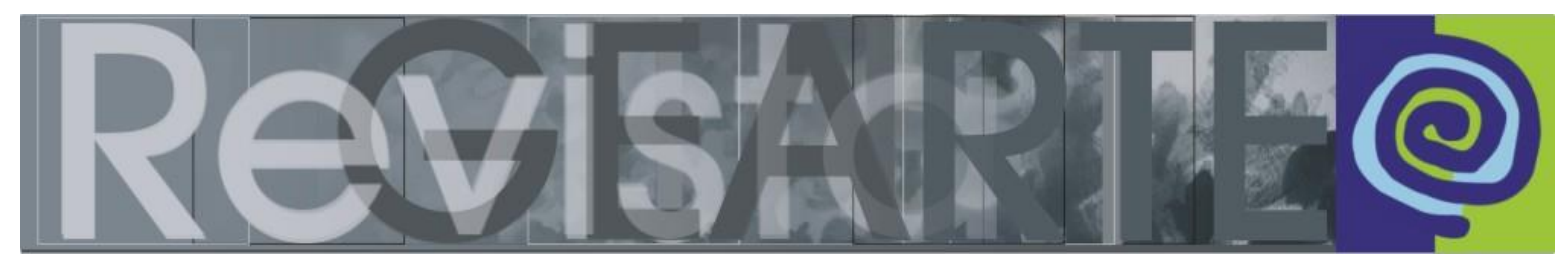

Volume 1, Número 1, Abril/2014, ISSN 2357-9854

\title{
Editorial
}

\section{A pesquisa no ensino de artes visuais: inquietações}

Numa época de rupturas de territórios, de conexões em redes, de criações transdisciplinares, a Revista GEARTE surge como uma possibilidade de interligar grupos de pesquisas interessados em questionar, analisar e transformar o ensino de arte, seja na escola, nos museus ou em contextos não formais. Com o intuito de adensar o campo do ensino das artes visuais, a revista busca congregar estudos e pesquisas que estão sendo realizados nessa área no país em diálogo com trabalhos desenvolvidos em outros países. O fio condutor deste primeiro número são as inquietações provocadas pela pesquisa no ensino de artes visuais em diferentes contextos.

No Brasil, as pesquisas acadêmicas voltadas ao ensino da arte começaram a se consolidar na década de 1980, com a criação por Ana Mae Barbosa dos cursos de mestrado e de doutorado em Arte-Educação na Escola de Comunicações e Artes da Universidade de São Paulo. Hoje várias universidades possuem em seus Programas de Pós-Graduação, tanto da área de artes como da área da educação, linhas de pesquisa voltadas ao ensino da arte com diversas abordagens teóricas. No entanto, nossa trajetória de pesquisa em ensino de artes visuais é bastante jovem, se compararmos a de outros países com tradição em pesquisa nessa área, mas, e talvez por isso, muito inquieta e disposta a adentrar esse campo criando links entre autores, linguagens, territórios.

Ana Mae Barbosa, no texto O Teachers College e sua influência na modernização da educação no Brasil, nos brinda com uma pesquisa histórica empreendida junto a documentos raros e arquivos do Teachers College, da Columbia University de Nova lorque, em que mostra as influências exercidas por essa Instituição no ensino de arte dos Estados Unidos e sua relação com o Brasil desde o século XIX. A autora observa que no início do século XX o Teachers College tornou-se uma 
instituição de liderança no ensino da arte e que na base de seus ensinamentos estava a ideia de que era preciso fazer arte e apreciá-la. Observa, também, que havia uma preocupação em organizar cursos extracurriculares de educação em museus. Desde 1916 alunos brasileiros receberam diploma de Mestrado no Teachers College, sendo que vários desses educadores foram importantes professores e gestores no Brasil, como Anísio Teixeira. O mais famoso intercâmbio com o Teachers College foi apelidado de "Embaixada de Minas Gerais" (1927/28), com a ida de cinco jovens professoras de Belo Horizonte para lá estudarem. São apresentadas as percepções e impressões acerca da arte, de uma dessas alunas, Profa. Alda Lodi, como também da estudante Benedicta Valladares, diante da realidade vivenciada no Teachers College.

Em Um breve histórico dos Fóruns de Pós-Graduação e Graduação em Artes Visuais, Milton Sogabe aborda a pesquisa sistematizada em arte vinculando-a à implantação dos cursos de pós-graduação em artes no país e contextualiza as mudanças que ocorreram nos cursos em relação às políticas educacionais. $O$ texto apresenta um mapeamento da organização do ensino de artes tanto na pósgraduação como na graduação, enfocando a importância do surgimento do Fórum de Coordenadores dos Cursos de Pós-Graduação em Artes Visuais no país, em 2004, e do Fórum de Coordenadores dos Cursos de Graduação em Artes Visuais, em 2012, para as conquistas que a área tem conseguido junto aos órgãos avaliativos e de fomento.

No texto Criando fluxos de investigações efervescentes entre Espanha e Brasil, María Acaso e Analice Pillar traçam um perfil das investigações que estão sendo realizadas nos coletivos Pedagogías Invisibles e Grupo de Pesquisa em Educação e Arte (GEARTE), buscando afinidades entre os trabalhos. Pedagogías Invisibles, coordenado por María Acaso, reúne pesquisadores vinculados à Universidad Complutense de Madrid (UCM) e outros profissionais interessados em problematizar a visualidade no ensino da arte na escola, em museus e em centros comunitários. GEARTE, coordenado por Analice Pillar e Maria Helena Rossi, está vinculado à Universidade Federal do Rio Grande do Sul (UFRGS) e vem, desde 1997, investigando as relações entre arte e educação em diferentes linguagens e contextos. 
Os dois grupos têm como aportes de suas pesquisas a semiótica e a cultura visual, em diálogo com outras teorias e, ultimamente, têm enfocado a leitura da visualidade.

Teresa Eça, pesquisadora do "Grupo de Investigação em Arte Educação C3", da Universidade do Porto/Portugal, no artigo Submergir-se: incorporar espaços (in)habitáveis, relata alguns projetos de investigação colaborativa realizados por professores, em contextos de educação formal e não formal, no Brasil e em Portugal. Com foco nos entre-lugares, nos espaços de fronteira tensionados, o texto descreve estratégias de performances artísticas como pedagogia em espaços de construção colaborativa de aprendizagem e nos convoca a dar mais visibilidade a uma arte/educação comprometida com o contexto em que se insere. Aborda, também, a necessidade de um trabalho em rede explorando as potencialidades das tecnologias da comunicação.

O artigo de Umbelina Barreto, Licenciaturas internacionais: uma experiência de aprendizagem transcultural na redefinição da formação do professor de artes visuais na Universidade Federal do Rio Grande do Sul, aborda o Programa de Licenciaturas Internacionais (PLI) - criado pela CAPES com o objetivo de oportunizar a dupla diplomação por meio de uma "graduação-sanduíche" em Portugal - enfocando a participação de sete alunos do Curso de Artes Visuais da UFRGS no Programa. O texto menciona mudanças no Ensino Superior Brasileiro a partir das transformações ocorridas nas IES após a LDB 9394/96, discutindo, conceitual e historicamente, as influências teóricas sofridas pela educação brasileira. Aborda o curso pela sua arquitetura - considerada como um campo curricular expandido - de modo a ultrapassar o seu próprio limite cultural e como os alunos podem experienciar um processo de aprendizagem transcultural. Por fim, a autora aponta perspectivas, enfatizando a pesquisa e a extensão como constituintes necessárias da formação do professor/pesquisador/curador.

O texto A pesquisa no campo da arte-educação visual e o ensino da arte na educação básica, de Maria Helena Wagner Rossi, traz uma discussão política sobre o modo como a educação é considerada - ou desconsiderada - no contexto brasileiro, mostrando através de diferentes documentos os índices de desenvolvimento no Brasil e a discrepância em relação aos investimentos em educação. Aborda o ensino da arte situando historicamente sua inserção no currículo escolar da educação básica e lança 
questionamentos quanto à formação de professores e às relações entre a produção oriunda dos programas de pós-graduação e o ensino da arte na educação básica.

O ensaio visual Pensando Moçambique, de Umbelina Barreto, foi criado a partir de sua viagem acadêmica ao país africano, particularmente à capital, Maputo. É vinculado à sua pesquisa sobre ensino de artes visuais. As imagens foram capturadas pela autora em Maputo e no Museu de História Natural de Moçambique. Sabemos que um ensaio visual é para ser olhado e não para ser traduzido em palavras, mas é para apresentá-lo que este trecho foi escrito: Num primeiro olhar vemos imagens em camadas; figuras que aparecem e desaparecem; pessoas, animais, máscaras, seres estranhos... Mas o que é estranho e de difícil interpretação para nós, já que enfoca uma cultura distante, vai ganhando sentido quando os olhos percorrem as veladuras, as sobreposições, as mesclas das imagens indissociadas das palavras. A quase monocromia tende às cores da terra, mas também evoca a cor da pele das etnias enraizadas no território africano. Imagens relativas à etnia maconde são mescladas com as do próprio Museu e iluminadas pela poesia do escritor moçambicano Mia Couto, que, segundo a artista, proporcionou-lhe o "entendimento da relação com a terra africana". A rica estatuária maconde, suas danças, máscaras do "Mapico" (complexo de crenças e atividades rituais), costumes, animais... surgem em bela interação com a palavra da poesia, tendo o museu que preserva essa cultura como pano de fundo. O olhar antropológico da autora permite que o nosso olhar - carente de significados sobre aquela cultura - possa se enriquecer pela leitura estética e, com isso, experimentar o olhar do outro e sentir as ressonâncias da ancestralidade aludida no ensaio.

Por fim, agradecemos a todos que tornaram possível o lançamento deste primeiro número da Revista GEARTE, em especial, aos autores e avaliadores, e desejamos uma boa leitura. 